\title{
Effect of Stem Cells and Gene Transfected Stem Cells Therapy on the Pancreas of Experimentally Induced Type 1 Diabetes
}

\author{
Maha Baligh Zickri ${ }^{1,2}$, Gihan Ibrahim Aboul-Fotouh ${ }^{1}$, Abeer Ibraheem Omar ${ }^{1}$, \\ Asmaa Ahmed El-Shafei ${ }^{1}$, Ahmed Mahmoud Reda ${ }^{3}$ \\ ${ }^{I}$ Department of Medical Histology $\mathcal{G}$ Cell Biology, Faculty of Medicine, Cairo University, Cairo, Egypt, \\ ${ }^{2}$ Faculty of Oral and Dental Medicine, Future University, Cairo, Egypt (FUE), \\ ${ }^{3}$ Clinical Pharmacy, Near East University North Cyprus, German University in Cairo, Cairo, Egypt
}

Background and Objectives: Insulin secretion entirely depends on $\mathrm{Ca}^{2+}$ influx and sequestration into endoplasmic reticulum (ER) of $\beta$-cells, performed by Sarco-ER $C a^{2+}$-ATPase $2 b$ (SERCA2b). In diabetes, SERCA2b is decreased in the $\beta$-cells leading to impaired intracellular $\mathrm{Ca}^{2+}$ homeostasis and insulin secretion. Adipose mesenchymal stem cells (AMSCs) play a potential role in transplantation in animal models. The present study aimed at investigating and comparing the therapeutic effect of non-transfected AMSCs and SERCA2b gene transfected AMSCs on the pancreas of induced diabetes type 1 in rat.

Methods and Results: 58 adult male albino rats were divided into: Donor group: 22 rats, 2 for isolation, propagation and characterization of AMSCs and SERCA2b transfected AMSCs, in addition 20 for isolated islet calcium level assessment. Group I (Control Group): 6 rats, Group II (Diabetic Group): 10 rats, 50 mg streptozotocin (STZ) were injected intraperitoneal (IP), Group III (AMSCs Group): 10 rats, $1 \times 10^{6}$ AMSCs were injected intravenous and Group IV (SERCA2b transfected AMSCs Group): 10 rats, $1 \times 10^{6}$ SERCA2b transfected AMSCs were injected as in group III. Groups I, II, III and IV were sacrified 3 weeks following confirmation of diabetes. Serological, histological, morphometric studies and quantitative polymerase chain reaction (qPCR) were performed. Nuclear, cytoplasmic degenerative and extensive fibrotic changes were detected in the islets of group II that regressed in groups III and IV. Isolated islet calcium, blood glucose, plasma insulin and qPCR were confirmative.

Conclusions: AMSCs and SERCA2b gene transfected AMSCs therapy proved definite therapeutic effect, more obvious in response to SERCA2b gene transfected AMSCs.

Keywords: AMSCs, SERCA2b, Type 1 diabetes, Pancreas

Received January 13, 2018, Revised March 11, 2018, Accepted May 1, 2018, Published online August 31, 2018

Correspondence to Maha Baligh Zickri

Department of Medical Histology \& Cell Biology, Faculty of Medicine, Cairo University, Cairo 0104, Egypt

Tel: +20123955078, Fax: +20235381183/+20235381760

E-mail: mahakaah2004@yahoo.com

(a) This is an open-access article distributed under the terms of the Creative Commons Attribution Non-Commercial License (http://creativecommons.org/ licenses/by-nc/4.0/), which permits unrestricted non-commercial use, distribution, and reproduction in any medium, provided the original work is properly cited.

Copyright (c) 2018 by the Korean Society for Stem Cell Research

\section{Introduction}

Diabetes mellitus is a global epidemic problem that causes public health crisis worldwide. In 2011, there were 366 million diabetic patients. This value was estimated to rise up to 522 million in 2030 (1). Diabetes is one of the most recognizable endocrine metabolic disorders characterized by chronic hyperglycemia. Over time, it increased the risk of heart disease, stroke, diabetic nephropathy and blindness (2). Type 1 diabetes (T1DM), the chronic autoimmune disease, results from the destruction of the in- 
sulin producing beta $(\beta)$ cells of the pancreas, leading to a gradual decrease in $\beta$-cell mass. Accordingly, this type of diabetes shows absolute insulin deficiency and excessive glucose production (3).

In recent years, stem cell therapies had opened up new horizons to treatment of diabetes mellitus. Mesenchymal stem cells (MSCs) had been shown to be an interesting therapeutic option based on their immunomodulatory properties and differentiation potentials confirmed in various experimental and clinical trial studies (4). Adipose-derived mesenchymal stem cells (AMSCs) play a potential role as seeding cells in stem cell transplantation in animal models (5).

It was approved that sarco (endo) plasmic reticulum calcium-ATPase (SERCA) 2b is the predominant SERCA isoform expressed in the pancreatic islet. In pancreatic $\beta$-cells, the metabolism of glucose results in closure of ATP-sensitive K-channels (KATP) channels resulting in depolarization of the $\beta$-cell. The L-type $\mathrm{Ca}^{2+}$ channel opens and allows the entry of $\mathrm{Ca}^{2+}$ from the extracellular compartment. Then the $\mathrm{P} / \mathrm{Q}$ type $\mathrm{Ca}^{2+}$ channels open triggering the exocytosis of insulin granules. Insulin secretion entirely depends on $\mathrm{Ca}^{2+}$ influx and sequestration into ER. In order to restore $\mathrm{Ca}^{2+}$ resting levels, cytosolic $\mathrm{Ca}^{2+}$ is pumped inside the ER by the SERCA2b. In the diabetic pancreas, the amount of SERCA2b is decreased in the $\beta$-cells leading to impaired intracellular $\mathrm{Ca}^{2+}$ homeostasis and insulin secretion. Increasing the level of SERCA2b in pancreas by gene therapy is a promising therapeutic strategy to correct alterations in $\mathrm{Ca}^{2+}$ handling in diabetic patients (6).

Transfection of MSCs in different tissue cultures had been approved. Lipid-mediated transfection remained popular due to ease of use, low cost and adaptation to high throughput system (7).

The present study aimed at investigating the therapeutic effect of SERCA2b gene transfected AMSCs on the pancreas of streptozotocin (STZ)-induced diabetes type 1 in adult male albino rat and comparing it to that of non-transfected AMSCs.

\section{Materials and Methods}

\section{Experimental design}

This study was conducted on 58 adult male albino rats with average body weight 200 grams, housed according to the guidelines of Cairo University and were divided into the following:

\section{Donor Group}

It included 22 rats divided into: Two rats were used for stem cell isolation, culture, phenotyping and labeling. In addition, a part of pancreas was homogenized for SERCA2b preparation.

Twenty rats were used for isolation of the islets from the rats' pancreases to assess the islet calcium level. They were subdivided into 4 subgroups (5 rats each).

Group I (Control Group): It included 6 rats that corresponded to and were sacrificed with the experimental groups II, III and IV respectively. The first 2 rats received a single intraperitoneal (IP) injection of $0.5 \mathrm{ml}$ citrate buffer. The second 2 rats received a single IP injection of $0.5 \mathrm{ml}$ citrate buffer. The day following confirmation of diabetes, $1 \mathrm{ml}$ of phosphate buffered saline (PBS) was given intravenous (IV) via tail vein. The third 2 rats received citrate buffer and PBS as for the $2^{\text {nd }} 2$ rats, in addition to $1.5 \mu 1$ lipofectamine via the tail vein.

Group II (Diabetic Group): It included 10 rats. Diabetes was induced by a single IP injection of STZ (Sigma Company, St. Louis, Mo, USA) in a powder form as $1 \mathrm{~g}$ vial. The required dose (50 $\mathrm{mg} / \mathrm{kg}$ body weight) (8) was weighed using a digital scale and dissolved in 0.5 citrate buffer for each rat. Three days following STZ injection, diabetes was confirmed by measuring the blood glucose level. The animals were considered diabetic if their blood glucose level was higher than $200 \mathrm{mg} / \mathrm{dl}$ (9).

Group III (AMSCs Group): It included 10 rats. On the day following confirmation of diabetes, $1 \times 10^{6}$ of cultured and labeled rat AMSCs, suspended in $1 \mathrm{ml}$ PBS, were injected into the tail vein (10).

Group IV (SERCA2b transfected AMSCs Group): It included 10 rats. On the day following confirmation of diabetes, $1 \times 10^{6}$ of cultured and labeled SERCA2b transfected AMSCs were injected as in group III.

In group I (control) and the corresponding experimental groups II, III and IV, the rats were sacrified 3 weeks following the day of confirmation of diabetes.

\section{In Vitro Studies}

Isolation and propagation of AMSCs from rats (11, 12): Under sterile conditions, rats were euthanized with carbon dioxide $\left(\mathrm{CO}_{2}\right)$, their abdomens were cut open and the adipose tissues were removed. After the adipose tissues were washed with saline solution, all the tissues were collected and incubated in Dulbecco's modified Eagle's medium (DMEM), (GIBCO/BRL) supplemented with 10\% fetal bovine serum (FBS) (GIBCO/BRL). Nucleated cells were isolated with a density gradient [Ficoll/Paque (Pharmacia)] and resuspended in complete culture me- 
dium supplemented with $1 \%$ penicillin-streptomycin (GIBCO/BRL). Cells were incubated at $37^{\circ} \mathrm{C}$ in $5 \%$ humidified CO2 for $12 \sim 14$ days as primary culture or upon formation of large colonies. When large colonies developed (80 90\% confluence), cultures were washed twice with PBS and cells were trypsinized with $0.25 \%$ trypsin in 1millimolar EDTA (GIBCO/BRL) for 5 minutes at $37^{\circ} \mathrm{C}$. After centrifugation (at $2400 \mathrm{rpm}$ for 20 minutes), cells were resuspended with serum-supplemented medium and incubated in $50 \mathrm{~cm} 2$ culture flask Falcon). The resulting cultures were referred to as first-passage cultures. On day 14 , the adherent colonies of cells were trypsinized, and counted.

Characterization of AMSCs: Adherent cells (at the end of 3 rd passage) were trypsinized and adjusted to $1 \times 10^{6}$ cells $/ \mathrm{ml}$ determined by hemocytometer and incubated with $10 \mu 1$ of monoclonal antibodies: CD34 and CD44 (Beckman coulter, USA) at $4^{\circ} \mathrm{C}$ in the dark. After $20 \mathrm{mi}-$ nutes incubation, $2 \mathrm{ml}$ of PBS containing 2\% fraction crystallizable solution (FCS) were added to each tube of monoclonal treated cells. The mixtures were then centrifuged for 5 minutes at $2500 \mathrm{rpm}$ followed by discarding the supernatant and resuspending cells in $500 \mu 1$ PBS containing 2\% FCS. Cell analysis was performed using CYTOMICS FC 500 Flow Cytometer (Beckman coulter, FL, USA) and analyzed using CXP Software version 2.2 (10). Immunohistochemical characterization was performed by using streptavidin immunoperoxidase technique for CD44 and CD34 (13).

Labeling of stem cells with PKH26 dye (14): Non-transfected AMSCs cells were harvested during the 4th passage and were labeled with PKH26 fluorescent linker dye to be examined by fluorescent microscope.

SERCA2b preparation: Pancreatic tissues were homogenized in a solution containing (mM) 250 sucrose, 5 hydroxyethylpiperazine-N'-2-ethanesulfonic acid (HEPES) and 0.2 phenylmethanesulfonyl fluoride (PMSF), using a Polytron homogenizer. $\mathrm{Ca}^{2+-}$ dependent $\mathrm{Ca}^{2+-}$ ATPase activity in homogenates was measured at $37^{\circ} \mathrm{C}$. The data were analyzed by nonlinear regression with computer software (GraphPad Software). Processing for ribonucleic acid (RNA) extraction was followed by using reverse transcriptase (for complementary DNA (cDNA) synthesis (15).

Lipofectamine 3000 transfection and characterization of transfected cells (16): The cells were plated at a confluency of $50 \%(500,000$ cells/plate $)$ one day prior to transfection. $1.5 \mu 1$ Lipofectamine 3000 reagent (Invitrogen) and $1.5 \mu \mathrm{g}$ SERCA2b labeled with green fluorescent protein (GFP) were used for transfection using serum-free DMEM. GFP directly fuses to selected loca- tions on SERCA2b (17). Culture media were changed 4 hours after transfection and replaced with DMEM/10\% FBS without antibiotics. To assess transfection efficiency, cells labeled with GFP are first visualized via fluorescence microscopy for qualitative assessment of protein expression, morphology and viability. Cells were then prepared for flow cytometry by aspirating the medium and replacing it with $250 \mu 1$ of a $7: 3$ mixture of TrypLE reagent:1 X DPBS. Cells were incubated at $37^{\circ} \mathrm{C}$ for $10 \mathrm{~min}$ and then pipetted up and down to ensure single cells for flow cytometry analysis. The cells were then allowed to proliferate and differentiate in DMEM/2\% FBS.

Isolation of pancreatic islets (18): Pancreatic islets were aseptically isolated from rat pancreases according to the optimized protocol described by Shewade et al. (16). Aseptically excised rat pancreases were minced into three 1-mm pieces and digested with collagenase (Sigma Aldrich, USA) $(1 \mathrm{mg} / \mathrm{ml})$ for $10 \mathrm{~min}$. The collagenase was then inactivated with two washes of RPMI 1640 containing $10 \%$ fetal calf serum (Sigma Aldrich, USA) and the samples were seeded into the same medium at one pancreas per flask. The primary cultures were incubated at $37^{\circ} \mathrm{C}$ under $5 \% \mathrm{CO} 2$ for $48 \mathrm{~h}$. The isolated islets of the 1 st subgroup were considered control. The isolated islets of the 2nd subgroup were exposed to STZ (5 $\mathrm{mM}$ ) for 1 $\mathrm{h}$ at $37^{\circ} \mathrm{C}$. The STZ solution was prepared in phosphate-buffered saline (Sigma Aldrich, USA). The isolated islets of the 3rd subgroup were exposed to STZ (5 $\mathrm{mM})$ for $1 \mathrm{~h}$ and then treated with AMSCs $(10 \mu \mathrm{M})$. The isolated islets of the 4th subgroup were exposed to STZ (5 $\mathrm{mM})$ for $1 \mathrm{~h}$ and then treated with SERCA $2 b$ transfected AMSCs $(10 \mu \mathrm{M})$.

Assessment of islet calcium level (19): The calcium level was assessed in the islet culture medium after treatment by colorimetric methods according to the kit instructions. The analytical kits were supplied by Quimica Clinica Aplicada SA (Amposta, Spain).

\section{Animal studies}

Serological study: Before sacrifice tail vein blood samples were collected at the end of the $3^{\text {rd }}$ week from groups I, II, III and IV for blood glucose and plasma insulin levels estimation.

Plasma insulin level was measured by enzyme immunoassay of 25-1 aliquots of plasma with a Rat Insulin ELISA kit (DRG, USA). During incubation, insulin in the sample reacted with peroxidase-conjugated anti-insulin antibodies, which were bound to the plastic surface of the microtitration well. The bound conjugate was detected by reaction with 3, 3`, 5, 5 '-tetramethylbenzidine. The reaction 
was stopped by adding acid to give a colorimetric end point that was read spectrophotometrically (20).

Histological study: The animals were sacrificed by cervical dislocation (21). A central ventral midline incision was performed for each animal. The pancreas specimens were excised and fixed in 10\% formol saline for 48 hours. Paraffin blocks and $5 \mu \mathrm{m}$ thick sections were prepared. For semithin sections, pancreas specimens $(1 \mathrm{~mm})$ were processed for embedding in epoxy resin, cut atl $\mu \mathrm{m}$ thickness and staind with toluidine blue. Sections were subjected to

1. Toluidine blue stain (22)

2. Masson's trichrome stain (23).

3. CD44 (IW-PA1021, IHW, Ellicott City, USA) immunostaining, for detecting endogenous and exogenous undifferentiated MSCs (24).

4. Insulin (EPR17359 Ab, Abcam, USA) immunostaining, for detecting $\beta$ cells (25).

$0.1 \mathrm{ml}$ prediluted primary rabbit polyclonal CD44 antibody was applied to sections for 60 minutes, tonsil sections were considered + ve control and the reaction is membranous. $0.1 \mathrm{ml}$ diluted 1ry antibody rabbit monoclonal insulin antibody was applied to sections for $60 \mathrm{mi}-$ nutes pancreas sections were considered + ve control and the reaction is cytoplasmic,

Morphometric study: Using Leica Qwin 500 LTD (Cambridge, UK) computer assisted image analysis system, assessment of the area percent (\%) of collagen fibers performed in Masson's trichrome stained sections. The measurements were done in 10 low power fields (PFs) in control and experimental groups. Insulin IE and CD44 + ve cells were measured using binary mode. The measurements were done in 10 high PFs in control and experimental groups. The areas of chosen colors were masked by a blue binary color inside a standard measuring frame of area.

Quantitative polymerase chain reaction (qPCR): Evaluation of formalin-fixed paraffin-embedded (FFPE) pancreas specimens by real time qPCR was performed (26). Reverse Transcription is carried out with the SuperScript First-Strand Synthesis System for reverse transcriptase (RT)-PCR. The following procedure is based on Invitrogen's protocol. The SERCA2b primer using the 5'-oligonucleotide primer 5'-AC GTC AAT GGG TCG ACT ATT TAC G-3' and 3'-oligonucleotide primer 5'-AGA AGG CAC AGT CGA GGC TG-3' (mixture was prepared in each tube: $5 \mu \mathrm{g}$ total RNA and $3 \mu \mathrm{l}$ random hexamers). The samples were incubated at $65^{\circ} \mathrm{C}$ for $5 \mathrm{~min}$ and then on ice for at least $1 \mathrm{~min}$. Reaction master mixture was prepared for each reaction then added to the
$\mathrm{RNA}$ /primer mixture, mix briefly, and then placed at room temperature for 2 minutes. $1 \mu 1$ (50 units) of SuperScript II RT was added to each tube, mixed and incubated at $25^{\circ} \mathrm{C}$ for $10 \mathrm{~min}$. The tubes were incubated at $42^{\circ} \mathrm{C}$ for $50 \mathrm{~min}$, heat inactivated at $70^{\circ} \mathrm{C}$ for $15 \mathrm{~min}$, and then chilled on ice. $1 \mu 1$ RNAase $\mathrm{H}$ was added and incubated at $37^{\circ} \mathrm{C}$ for $20 \mathrm{~min}$. The 1st strand complementary deoxyribonucleic acid (cDNA) was stored at $-20^{\circ} \mathrm{C}$ until use for real-time PCR. The primer concentrations were normalized, gene-specific and reverse primer pair were mixed. Each primer (forward or reverse) concentration in the mixture is $5 \mathrm{pmol} / \mu \mathrm{l}$. The PCR program was set up on ABI Prism standard deviation score (SDS) 7000. A copy of the setup file was saved and all PCR cycles were deleted (used for later dissociation curve analysis). $50^{\circ} \mathrm{C}$ 2 min, 1 cycle, $95^{\circ} \mathrm{C} 10 \mathrm{~min}, 1$ cycle, $95^{\circ} \mathrm{C} 15$ seconds $\rightarrow$ $60^{\circ} \mathrm{C} 30$ seconds $\rightarrow 72^{\circ} \mathrm{C} 30$ seconds, 40 cycles and $72^{\circ} \mathrm{C}$ $10 \mathrm{~min}, 1$ cycle. A real-time PCR reaction mixture can be either $50 \mu 1$ or $25 \mu 1$. After PCR is finished, the tubes were removed from the machine. The PCR specificity was examined by $3 \%$ agarose gel using $5 \mu 1$ from each reaction. The setup file was saved and the real-time PCR result was analyzed with the SDS 7000 software. $\beta$-actin was used as internal control to normalize values with the following primer (forward primer: 5'-CCT TCCTGGGCATGGAGTCCT-3' \& reverse primer: 5'GGAGCAATGATCTTGATCTTC-3' ).

Statistical analysis (27): Any significant ANOVA was followed by Bonferroni post-hoc test to detect which pairs of groups caused the significant difference. p-values $<0.05$ were considered statistically significant. Calculations were made on Statistical Package for the Social Sciences (SPSS) version 16.

\section{Results}

General observations included lethargy and polyurea noticed in diabetic rats that improved in treated groups. Death of 2 diabetic rats was recorded at the beginning of the experiment.

\section{In vitro data}

Characterization of AMSCs and transfected AMSCs: AMSCs appeared mostly spindle in shape, immunostaining showed + ve membranous brownish reaction for CD44 (arrows) (Fig. 1A) and -ve for CD34 (arrows) (Fig. 1B). Immunophenotyping of AMSCs by flow cytometry showed $96 \%$ of the cells +ve for CD44 (Fig. 1C).

Transfected cells appeared mostly as spindle fluroscent labeled cells (Fig. 1D). Immunophenotyping of transfected 

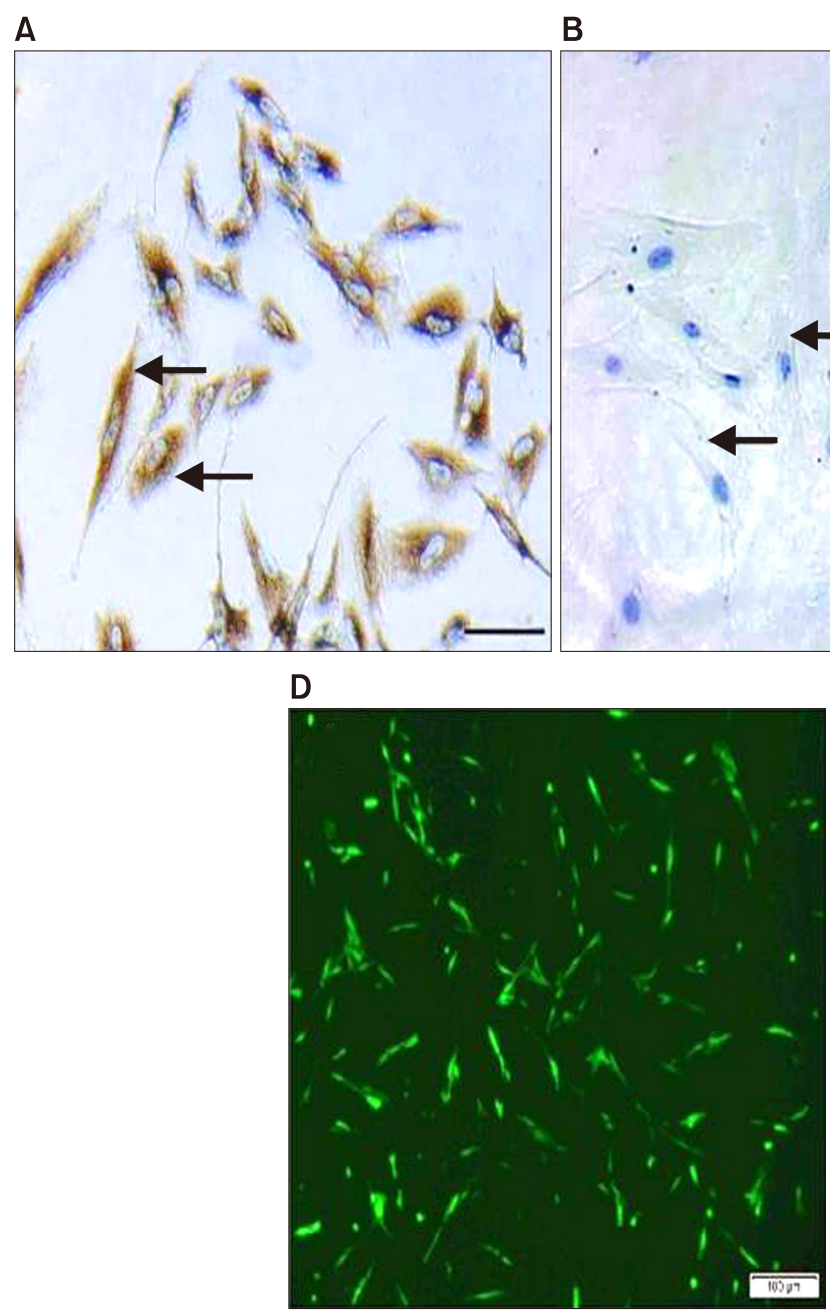

B

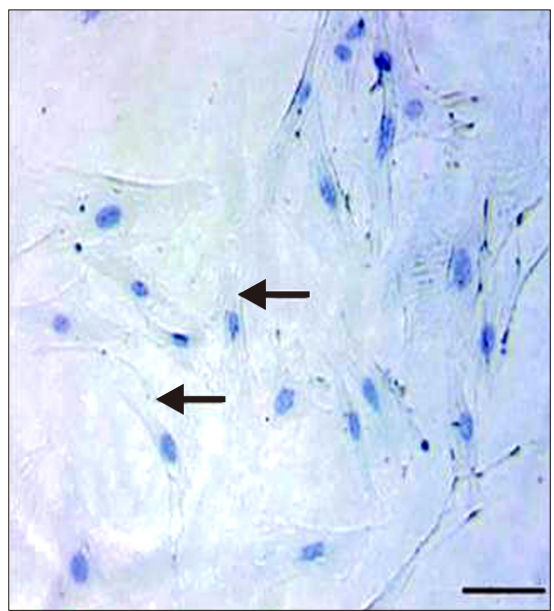

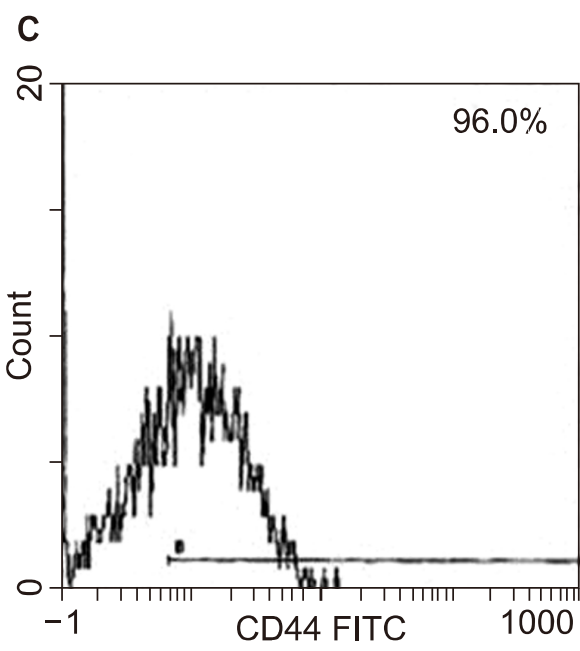

E

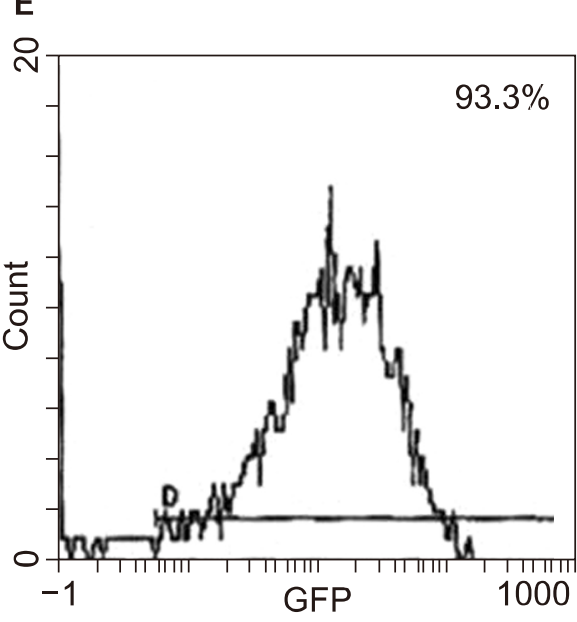

Fig. 1. Showing: (A) CD44 + ve spindle cells (arrows). (B) CD34 -ve immunoreactivity (arrows) (Phase contrast microscopy $\times 100$ ). (C) Immunophenotyping of AMSCs $96 \%$ are + ve for CD44 (Flow Cytometry). (D) Transfected cells appearing mostly as spindle fluroscent labeled cells $(\mathrm{GFP} \times 100)$. (E) Immunophenotyping of transfected AMSCs showed $93.3 \%$ of the cells GFP labeled (Flow Cytometry).

Table 1. Mean values \pm SD of blood glucose and plasma insulin levels in control and experimental groups

\begin{tabular}{lcc}
\hline Groups & Blood glucose level & Plasma insulin level \\
\hline Group I & $97.5 \pm 7.2 \mathrm{mg} / \mathrm{dl}$ & $0.89 \pm 0.02$ \\
Group II & $442.8 \pm 19.78 \mathrm{mg} / \mathrm{dl}^{\mathrm{a}}$ & $0.54 \pm 0.03^{\mathrm{b}}$ \\
Group III & $158.2 \pm 6.71 \mathrm{mg} / \mathrm{dl}$ & $0.67 \pm 0.03^{\mathrm{c}}$ \\
Group IV & $129.3 \pm 6.12 \mathrm{mg} / \mathrm{dl}$ & $0.84 \pm 0.04$ \\
\hline
\end{tabular}

${ }^{\mathrm{a} S}$ Significant increase compared to the other groups. ${ }^{\mathrm{b}}$ Significant decrease compared to the other groups. 'Significant decrease compared to groups I and IV.

AMSCs by flow cytometry showed $93.3 \%$ of the cells GFP labeled (Fig. 1E).

Islet calcium level: The mean calcium level values \pm standard deviation (SD) were $(1.41 \pm 0.03)$ in the con- trol group, $(0.77 \pm 0.02)$ in the diabetic group, $(1.03 \pm 0.04)$ in the AMSCs group and $(1.31 \pm 0.03)$ in the SERCA2b transfected AMSCs group. The previous values indicated a significant decrease in the diabetic group compared to the other groups and in the AMSCs group compared to control and transfected AMSCs group.

\section{Animal data}

Serological results: Blood glucose level values indicated a significant increase in the diabetic group before sacrifice compared to the other groups. The plasma insulin values revealed a significant decrease in the diabetic group compared to the other groups and in the AMSCs group compared to control and SERCA2b transfected AMSCs groups (Table 1).

Histological phenotyping: In toluidine blue stained 

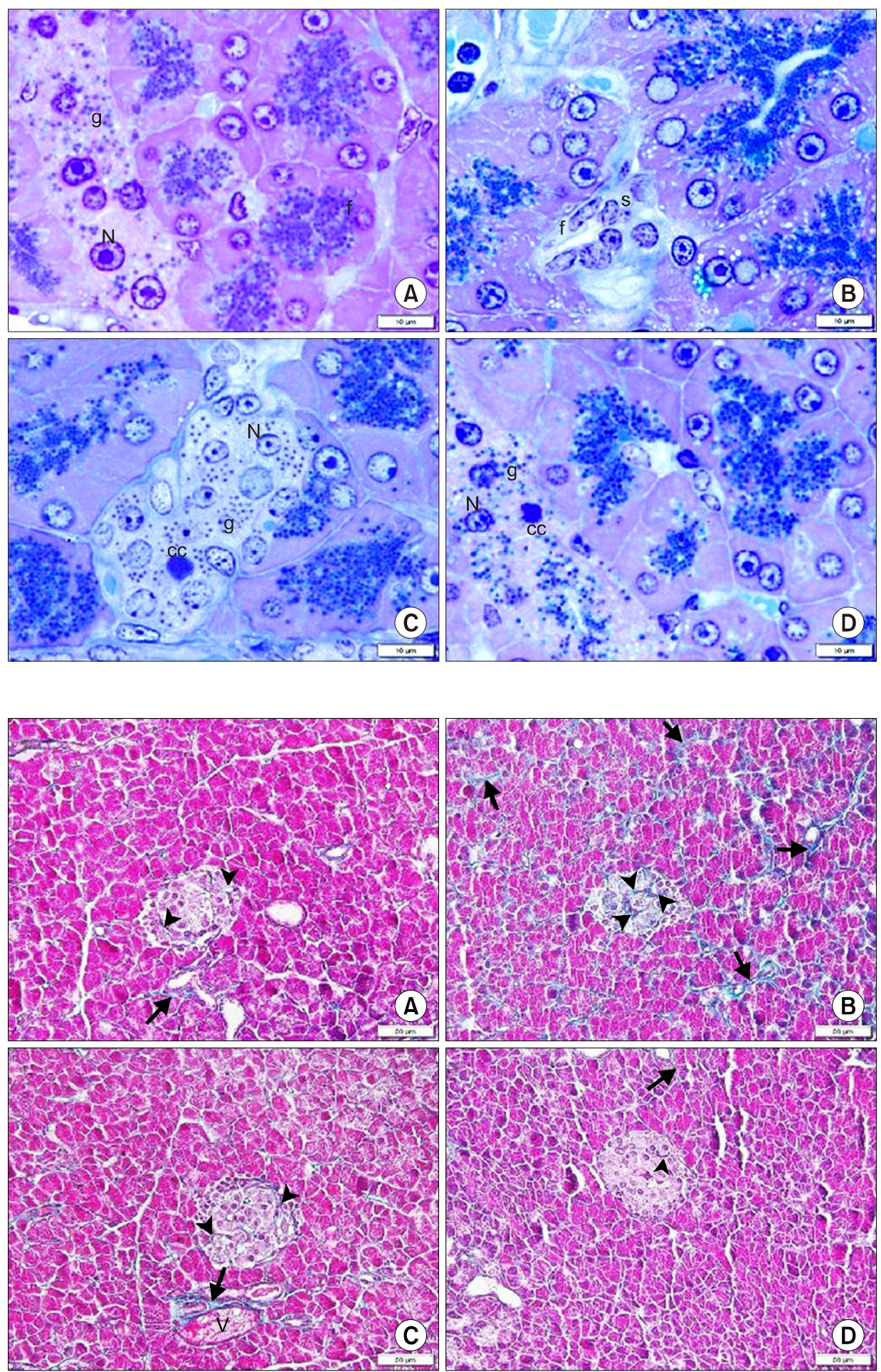

Fig. 2. Showing: (A) the islet cells exhibiting pale nuclei $(\mathrm{N})$ and secretory granules (g) in group I. (B) a shrunken islet (s) exhibiting fibroblasts (f) and few cells with absent secretory granules in group II. (C) condensed nuclear chromatin (cc) of an islet cell, multiple pale nuclei $(\mathrm{N})$ and secretory granules (g) in group III. (D) condensed nuclear chromatin (cc) of an islet cell, pale nuclei (N) and secretory granules (g) in most islet cells of group IV (Toluidine blue, $\times 1000)$.
Fig. 3. Showing: (A) fine collagen fibers between the acini (arrows) and among the islet cells (arrowheads) in group I. (B) multiple collagen fibers between the acini (arrows) and among the islet cells (arrowheads) in group II. (C) minimal increase in the collagen content (arrow) around a vessel $(\mathrm{V})$ and fine collagen fibers among the islet cells (arrowheads) in group III. (D) fine collagen fibers between the acini (arrow) and among the islet cells (arrowhead) in group IV (Masson's Trichrome, $\times 200$ ). sections, all control rats demonstrated islet cells exhibiting pale nuclei and secretory granules (Fig. 2A). Sections of group II recruited shrunken islets exhibiting few cells with absent secretory granules (Fig. 2B). Sections of group III showed condensed nuclear chromatin of few islet cells, multiple pale nuclei and secretory granules in most of islet cells (Fig. 2C). Sections of group IV demonstrated condensed nuclear chromatin of few islet cells, pale nuclei and secretory granules in most cells (Fig. 2D).

In Masson's trichrome stained sections, group I revealed 


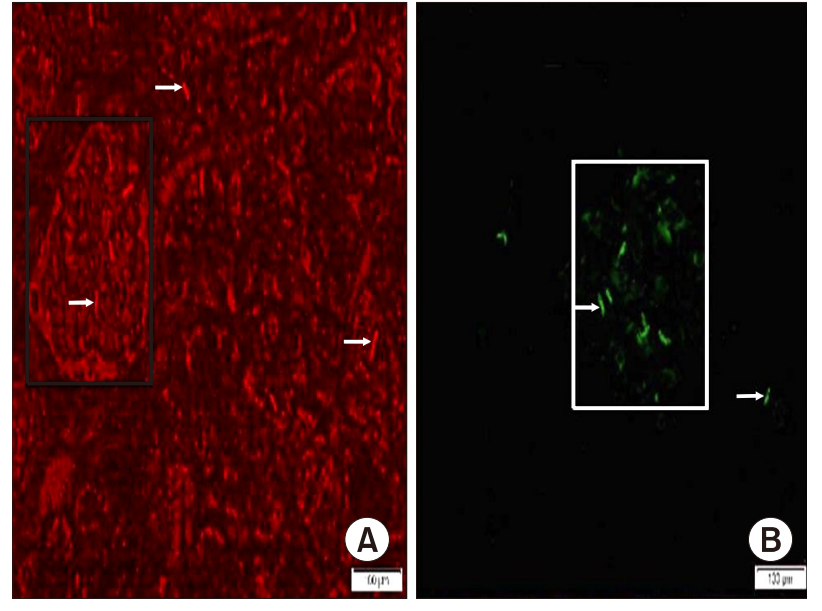

Fig. 4. Showing: (A) some fluorescent labeled cells (arrows) among pancreatic acini and an islet (rectangle) in group III (PKH26, $\times 100$ ). (B) Few fluorescent labeled cells (arrows) among pancreatic acini and an islet (rectangle) in group IV (GFP, $\times 100)$.

fine collagen fibers and group II recruited increased collagen fibers between the acini and among the islet cells (Fig. 3A, B). Group III demonstrated minimal increase in the collagen content around vessels and fine collagen fibers among the islet cells and group IV showed fine collagen fibers (Fig. 3C, D).

In fluorescent labeled sections, group III showed some PKH26 fluorescent labelled cells (Fig. 4A) and in group IV few GFP fluorescent labelled cells were evident among the acini and islets (Fig. 4B).

In CD44 immunostained sections, group I showed -ve IE (Fig. 5A). Group II demonstrated multiple +ve spindle cells among the islets and pancreatic acini in few fields (Fig. 5B). While group III recruited multiple + ve cells and group IV some + ve cells among the islets and acini in multiple fields (Fig. 5C, D).

In insulin immunostained sections, group I showed + ve IE among most of the islet cells, in group II shrunken islets recruited + ve IE among few cells, in group III +ve IE was seen among multiple islet cells and group IV clarified + ve IE among most of the islet cells (Fig. 6A, B, C, D).

Morphometric results (Table 2): Concerning the mean area $\%$ of collagen fibers, a significant increase was found in group II compared to the other groups. The mean area $\%$ of CD44 +ve cells revealed a significant increase in group III compared to groups II and IV, in addition in group IV compared to group II.

The mean area $\%$ of insulin + ve IE denoted a significant decrease in group II compared to the other groups and in group III compared to groups I and IV.
PCR results: The mean values of $\mathrm{PCR} \pm \mathrm{SD}$ were $(1.93 \pm 0.30)$ in group I, $(0.14 \pm 0.04)$ in group II, $(0.61 \pm 0.08)$ in group III and $(1.59 \pm 0.11)$ in group IV. The previous values indicated a significant decrease in the group II compared to the other groups and in group III compared to groups I \& IV.

\section{Discussion}

The present study aimed at investigating the therapeutic effect of SERCA2b gene transfected AMSCs on the pancreas of streptozotocin (STZ)-induced diabetes type 1 in adult male albino rat and comparing it to that of non-transfected AMSCs.

In the present study single dose of STZ has been administered to rodents, which were sacrified 3 weeks following the day of confirmation of diabetes. The aim was to establish a model of T1DM and provide the optimal time to assess serological and morphological events underlying T1DM in rat. This was confirmed by de Senna et al. (28).

Diabetic group (Group II) showed shrunken islets exhibiting few cells with absent secretory granules, denoting degenerative changes. Increased collagen content indicated fibrotic changes and was confirmed by a significant increase in the mean area \% of collagen fibers. In accordance, it was mentioned that decrease in number and size of the pancreatic islets and beta cells degranulation were commonly reported in T1DM. Oxidative stress and increased accumulation of ROS induce beta cell damage (29).

In group II, few CD44+ ve spindle cells were seen and a significant decrease in the mean area $\%$ of insulin + ve IE was recorded. The previous results indicated autoimmune destruction of the insulin producing $\beta$-cells as documented by Martinov et al. (30). It was proved that MSCs exhibit a surface marker profile + ve for CD44 (31). It was added that diabetes negatively impacts on functional properties of tissue resident SCs with consequent defective regeneration (32).

As regards PCR values, a significant decrease in $S E R C A 2 b$ gene was recorded in group II. In agreement, it was reported that islets isolated from diabetic $\mathrm{db} / \mathrm{db}$ mice lacked SERCA2b, the main SERCA isoform expressed in pancreatic $\beta$-cells, and revealed altered $\mathrm{Ca}^{2+}$ oscillations (6). In addition, a significant decrease was recorded in the mean isolated islet calcium values in the diabetic group. In support, it was mentioned that in STZ-treated isolated islet, the intracellular calcium level was decreased. This was referred to changes in the ex- 

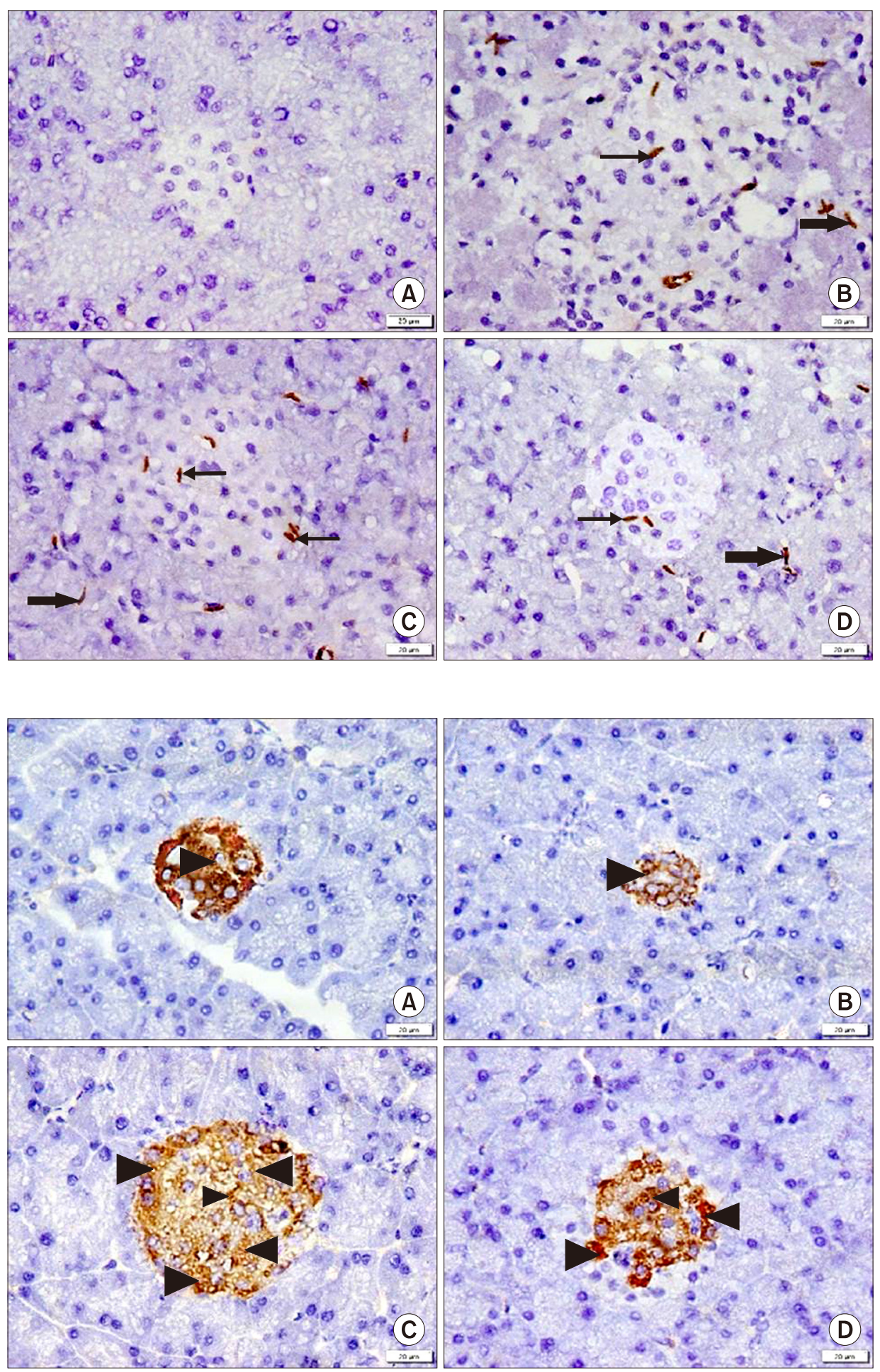

Fig. 5. Showing: (A) -ve IE in group I. (B) multiple + ve spindle cells among islet cells (arrows) and acini (thick arrow) in group II. (C) multiple +ve cells among islet cells (arrows) and acini (thick arrow) in group III. (D) some + ve cells among islet cells (arrow) and acini (thick arrow) in group IV (CD44 immunostaining, $\times 400$ ).
Fig. 6. Showing: +ve IE among (arrowhead): (A) most of islet cells in group I. (B) few cells in a shrunken islet of group II. (C) multiple islet cells in group III. (D) most islet cells in group IV (Insulin immunostaining, $\times 400)$. pression of cellular calcium-channels (Cav1.2 and PMCA). In addition, down-regulation of ER calcium- transporters such as SERCA2b implies depletion of the ER calcium pool resulting in ER stress (33).

A significant increase was reported in the mean blood glucose values in group II compared to the control and treated groups, in accordance to Li et al. (34). On the other hand, a significant decrease was detected in the mean plasma insulin values, the previous finding was confirmed in STZ-DM rats (19). 
Table 2. Mean \pm SD of the area $\%$ of collagen fibers, area $\%$ of CD44 + ve cells and area \% of insulin + ve IE in control and experimental groups

\begin{tabular}{lccc}
\hline Groups & $\begin{array}{c}\text { Area \% of } \\
\text { collagen fibers }\end{array}$ & $\begin{array}{c}\text { Area \% of } \\
\text { CD44 +ve cells }\end{array}$ & $\begin{array}{c}\text { Area \% of } \\
\text { insulin +ve IE }\end{array}$ \\
\hline Group I & $0.24 \pm 0.05$ & - & $1.24 \pm 0.15$ \\
Group II & $2.43 \pm 0.62^{\mathrm{a}}$ & $0.39 \pm 0.11$ & $0.25 \pm 0.08^{\mathrm{d}}$ \\
Group III & $0.28 \pm 0.05$ & $1.29 \pm 0.31^{\mathrm{b}}$ & $0.63 \pm 0.16^{\mathrm{e}}$ \\
Group IV & $0.26 \pm 0.04$ & $0.89 \pm 0.20^{\mathrm{c}}$ & $1.06 \pm 0.10$ \\
\hline
\end{tabular}

${ }^{\mathrm{a}}$ Significant increase compared to the other groups. ${ }^{\mathrm{b}}$ Significant increase compared to groups II and IV. 'Significant increase compared to group II. ${ }^{\mathrm{d}}$ Significant decrease compared to the other

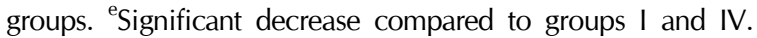

In AMSCs group, few islet cells with condensed nuclear chromatin were evident. The previous results indicated regression of induced diabetic degenerative changes by AMSCs therapy. This outcome was concomitant with Gerace et al. (35), who documented that MSC interventions demonstrated improved T1DM outcomes through MSC migration to areas of pancreatic injury. In addition, MSCs modify the islet microenvironment to promote the survival and regeneration of surviving $\beta$ cells and abrogate inherent autoimmunity against $\beta$ cells.

Group III showed minimal increase in the collagen content between the lobules, among the islet cells and around vessels. In support, it was suggested that the antifibrotic effect of MSCs is mediated through immune modulation, inhibition of TGF $\beta$-mediated differentiation of various cells types into myofibroblasts and inhibition of oxidative stress (36).

In group III characterization of the cultured cells by immunohistochemistry and immunophenotyping proved that they were CD44 +ve. Some PKH26 fluorescent labelled cells, in addition to multiple CD44+ ve cells were detected among the islet cells and acini in multiple fields. A significant increase in the mean area \% of CD44 + ve cells compared to groups II and IV was confirmative. The previous results denoted homing of the injected AMSCs, the ability of transplanted MSCs to engraft and regenerate injured tissues, in addition to increasing mobilization of the endogenous stem cells as confirmed by Aboul-Fotouh et al. (10).

Positive insulin IE was evident among multiple islet cells in the AMSCs group, confirmed by a significant increase in the mean area \% of IE compared to group II. In agreement, Liu et al. (37) mentioned that in case of treatment with MSCs, $\beta$-cells insulin immunoreactions were obviously improved and referred the previous findings to the multipotency of MSCs and their abililty to transdifferentiate into insulin producing $\beta$ cells.

SERCA2b transfected AMSCs group recruited accidental condensed nuclear chromatin and fine collagen fibers. The previous results denoted minimal residual degenerative and fibrotic changes compared to groups II and III. This denoted a rapid and effective regenerative process. In accordance, a novel therapeutic approach using $S E R C A 2 b$ gene was suggested to stabilize the intracellular $\mathrm{Ca}^{2+}$ level in the pancreas of diabetic patients (38).

In group IV, characterization of the cultured gene transfected AMSCs by GFP labeling and immunophenotyping proved transfection of more than $90 \%$ of cells. Few GFP labeled cells and fewer CD44 + ve cells were evident among the acini and islets, compared to group III. In addition, +ve insulin IE was found among most of the islet cells, confirmed by a significant increase in the mean area $\%$ of the IE compared to groups II and III.

The previous changes can be explained by more pronounced trans-differentiation of SERCA2b modified AMSCs into insulin producing $\beta$ cells with morphological trans-differentiation and higher efficiency of the $S E R C A 2 b$ modified AMSCs regenerative plasticity. In support, it was documented that normal regeneration, repair and consequently function of pancreatic $\beta$ cells can be referred to normal SERCA2b level. It was added that intracellular $\mathrm{Ca}^{2+}$ homeostasis is cruicial for cell proliferation, migration and differentiation (39).

As regards PCR values, a significant decrease in $S E R C A 2 b$ gene was recorded in AMSCs group compared to control and $S E R C A 2 b$ treated group. The previous finding can be referred to the injection of genetically modified AMSCs transfected by SERCA2b gene. Concomitantly, it was confirmed and proved that level of SERCA2a gene upgraded by gene therapy (40). In addition, a significant increase in isolated islet calcium level was recorded in $S E R C A 2 b$ treated group compared to group III providing more evidence to support that SERCA2b improves the therapeutic efficacy of AMSCs.

The lowered blood glucose level in AMSCs and $S E R C A 2 b$ transfected AMSCs treated groups can be related to regeneration of the islet $\beta$ cells and improved endogenous insulin secretion. In addition, a significant increase in plasma insulin and islet calcium levels was recorded in SERCA2b treated group compared to group III providing more evidence to support that $S E R C A 2 b$ improve the therapeutic efficacy of AMSCs, yet the recovery is better confirmed by all the assessment parameters.

It can be concluded that diabetes type 1 induced pancreatic degenerative changes. AMSCs and SERCA2b gene modified AMSCs therapy proved definite therapeutic ef- 
fect by regression of degenerative changes. The regenerative effect was more obvious in response to $S E R C A 2 b$ gene modified AMSCs, suggesting its potential use as a therapeutic modality for diabetes. The severity of degenerative changes and the comparative therapeutic effect were confirmed by histological, morphometric, biochemical and serological studies.

\section{Acknowledgements}

Professor Laila Ahmed Rashed, Department of Biochemistry, Faculty of Medicine, Cairo University, Egypt performed biochemical and serological procedures. Mr. Kareem Hassan technician at Medical Histology and Cell Biology Department contributed to specimens preparation.

\section{Potential Conflict of Interest}

The authors have no conflicting financial interest.

\section{References}

1. Whiting DR, Guariguata L, Weil C, Shaw J. IDF diabetes atlas: global estimates of the prevalence of diabetes for 2011 and 2030. Diabetes Res Clin Pract 2011;94:311-321

2. Mohamed SS, Ali EAI, Hosny S. The antidiabetic effect of mesenchymal stem cells vs. nigella sativa oil on streptozotocin induced type 1 diabetic rats. J Cell Sci Ther 2015;6: 226-235

3. Roh SS, Kwon OJ, Yang JH, Kim YS, Lee SH, Jin JS, Jeon YD, Yokozawa T, Kim HJ. Allium hookeri root protects oxidative stress-induced inflammatory responses and $\beta$-cell damage in pancreas of streptozotocin-induced diabetic rats. BMC Complement Altern Med 2016;16:63

4. Hashemian SJ, Kouhnavard M, Nasli-Esfahani E. Mesenchymal stem cells: rising concerns over their application in treatment of type one diabetes mellitus. J Diabetes Res 2015. doi: $10.1155 / 2015 / 675103$

5. Zhang W, Schmull S, Du M, Liu J, Lu Z, Zhu H, Xue $\mathrm{S}$, Lian F. Estrogen receptor $\alpha$ and $\beta$ in mouse: adipose-derived stem cell proliferation, migration, and brown adipogenesis in vitro. Cell Physiol Biochem 2016;38: 2285-2299

6. Zarain-Herzberg A, García-Rivas G, Estrada-Avilés R. Regulation of SERCA pumps expression in diabetes. Cell Calcium 2014;56:302-310

7. Yu X, Liang X, Xie H, Kumar S, Ravinder N, Potter J, de Mollerat du Jeu X, Chesnut JD. Improved delivery of Cas9 protein/gRNA complexes using lipofectamine CRISPRMAX. Biotechnol Lett 2016;38:919-929

8. Hidaka R, Machida M, Fujimaki S, Terashima K, Asashima M, Kuwabara T. Monitoring neurodegeneration in diabetes using adult neural stem cells derived from the olfactory bulb. Stem Cell Res Ther 2013;4:51
9. Bhansali S, Kumar V, Saikia UN, Medhi B, Jha V, Bhansali A, Dutta P. Effect of mesenchymal stem cells transplantation on glycaemic profile \& their localization in streptozotocin induced diabetic Wistar rats. Indian J Med Res 2015;142:63-71

10. Aboul-Fotouh GI, Zickri MB, Metwally HG, Ibrahim IR, Kamar SS, Sakr W. Therapeutic effect of adipose derived stem cells versus atorvastatin on amiodarone induced lung injury in male rat. Int J Stem Cells 2015;8:170-180

11. Takehara Y, Yabuuchi A, Ezoe K, Kuroda T, Yamadera R, Sano C, Murata N, Aida T, Nakama K, Aono F, Aoyama $\mathrm{N}$, Kato $\mathrm{K}$, Kato $\mathrm{O}$. The restorative effects of adipose-derived mesenchymal stem cells on damaged ovarian function. Lab Invest 2013;93:181-193

12. Espina M, Jülke H, Brehm W, Ribitsch I, Winter K, Delling U. Evaluation of transport conditions for autologous bone marrow-derived mesenchymal stromal cells for therapeutic application in horses. PeerJ 2016;4:e1773

13. Li H, Fu X, Ouyang Y, Cai C, Wang J, Sun T. Adult bone-marrow-derived mesenchymal stem cells contribute to wound healing of skin appendages. Cell Tissue Res 2006;326:725-736

14. Ude CC, Shamsul BS, Ng MH, Chen HC, Norhamdan MY, Aminuddin BS, Ruszymah BH. Bone marrow and adipose stem cells can be tracked with PKH26 until post staining passage 6 in in vitro and in vivo. Tissue Cell 2012;44: 156-163

15. Tupling AR, Bombardier E, Gupta SC, Hussain D, Vigna C, Bloemberg D, Quadrilatero J, Trivieri MG, Babu GJ, Backx PH, Periasamy M, MacLennan DH, Gramolini AO. Enhanced $\mathrm{Ca}^{2+}$ transport and muscle relaxation in skeletal muscle from sarcolipin-null mice. Am J Physiol Cell Physiol 2011;301:C841-C849

16. Mars T, Strazisar M, Mis K, Kotnik N, Pegan K, Lojk J, Grubic Z, Pavlin M. Electrotransfection and lipofection show comparable efficiency for in vitro gene delivery of primary human myoblasts. J Membr Biol 2015;248:273-283

17. Gruber SJ, Cornea RL, Li J, Peterson KC, Schaaf TM, Gillispie GD, Dahl R, Zsebo KM, Robia SL, Thomas DD. Discovery of enzyme modulators via high-throughput time-resolved FRET in living cells. J Biomol Screen 2014;19:215-222

18. Shewade YM, Umrani M, Bhonde RR. Large-scale isolation of islets by tissue culture of adult mouse pancreas. Transplant Proc 1999;31:1721-1723

19. Aziz MT, El-Asmar MF, Rezq AM, Wassef MA, Fouad H, Roshdy NK, Ahmed HH, Rashed LA, Sabry D, Taha FM, Hassouna A. Effects of a novel curcumin derivative on insulin synthesis and secretion in streptozotocin-treated rat pancreatic islets in vitro. Chin Med 2014;9:3

20. Su HC, Hung LM, Chen JK. Resveratrol, a red wine antioxidant, possesses an insulin-like effect in streptozotocin-induced diabetic rats. Am J Physiol Endocrinol Metab 2006;290:E1339-E1346

21. Golshan Iranpour F, Kheiri S. Coadministration of calcium chloride with lead acetate can improve motility of cauda 
epididymal spermatozoa in Swiss white mice. Int J Reprod Biomed (Yazd) 2016;14:141-144

22. Hunter EE. Practical electron microscopy. A Beginner's illustrated guide. 2nd ed. Cambridge, N Y, Melbourne, Madrid, Cape Town, Singapore, Sao Paulo, Delhi and UK: Cambridge university press; 1993. 1-70

23. Bancroft JD, Gamble M. Connective tissue stains. In: Theory and Practice of Histological Techniques. 6th ed. Edinburgh, London, Oxford, New York, Philadelphia, St Louis, Sydney and Toronto: Elsevier Health Sciences, Churchill Livingstone; 2008. 150

24. Steinert AF, Kunz M, Prager P, Göbel S, Klein-Hitpass L, Ebert R, Nöth U, Jakob F, Gohlke F. Characterization of bursa subacromialis-derived mesenchymal stem cells. Stem Cell Res Ther 2015;6:114

25. Yi P, Park JS, Melton DA. Betatrophin: a hormone that controls pancreatic $\beta$ cell proliferation. Cell 2013;153: 747-758

26. Pu T, Guo P, Qiu Y, Chen S, Yang L, Sun L, Ye F, Bu $\mathrm{H}$. Quantitative real-time polymerase chain reaction is an alternative method for the detection of HER-2 amplification in formalin-fixed paraffin-embedded breast cancer samples. Int J Clin Exp Pathol 2015;8:10565-10574

27. Emsley R, Dunn G, White IR. Mediation and moderation of treatment effects in randomised controlled trials of complex interventions. Stat Methods Med Res 2010;19:237-270

28. de Senna PN, Bagatini PB, Galland F, Bobermin L, do Nascimento PS, Nardin P, Tramontina AC, Gonçalves CA, Achaval M, Xavier LL. Physical exercise reverses spatial memory deficit and induces hippocampal astrocyte plasticity in diabetic rats. Brain Res 2017;1655:242-251

29. Zheng S, Zhao M, Wu Y, Wang Z, Ren Y. Suppression of pancreatic beta cell apoptosis by Danzhi Jiangtang capsule contributes to the attenuation of type 1 diabetes in rats. BMC Complement Altern Med 2016;16:31

30. Martinov T, Spanier JA, Pauken KE, Fife BT. PD-1 pathway-mediated regulation of islet-specific CD4 $+\mathrm{T}$ cell subsets in autoimmune diabetes. Immunoendocrinology (Houst) 2016;3 pii: e1164

31. Li S, Huang KJ, Wu JC, Hu MS, Sanyal $M$, Hu M,
Longaker MT, Lorenz HP. Peripheral blood-derived mesenchymal stem cells: candidate cells responsible for healing critical-sized calvarial bone defects. Stem Cells Transl Med 2015;4:359-368

32. Vono R, Fuoco C, Testa S, Pirrò S, Maselli D, Ferland McCollough D, Sangalli E, Pintus G, Giordo R, Finzi G, Sessa F, Cardani R, Gotti A, Losa S, Cesareni G, Rizzi R, Bearzi C, Cannata S, Spinetti G, Gargioli C, Madeddu P. Activation of the pro-oxidant PKC $\beta$ II-p66Shc signaling pathway contributes to pericyte dysfunction in skeletal muscles of patients with diabetes with critical limb ischemia. Diabetes 2016;65:3691-3704

33. Ahn C, Kang JH, Jeung EB. Calcium homeostasis in diabetes mellitus. J Vet Sci 2017;18:261-266

34. Li W, Du SN, Shi MJ, Sun ZZ. Spontaneous and transient predinner hyperglycemia in some patients with diabetes: Dusk phenomenon. Medicine (Baltimore) 2016;95:e5440

35. Gerace D, Martiniello-Wilks R, Nassif NT, Lal S, Steptoe $\mathrm{R}$, Simpson AM. CRISPR-targeted genome editing of mesenchymal stem cell-derived therapies for type 1 diabetes: a path to clinical success? Stem Cell Res Ther 2017;8:62

36. Spees JL, Lee RH, Gregory CA. Mechanisms of mesenchymal stem/stromal cell function. Stem Cell Res Ther 2016; 7:125

37. Liu HY, Chen CC, Lin YY, Chen YJ, Liu BH, Wong SC, Wu CY, Chang YT, Chou HE, Ding ST. Chitosan-assisted differentiation of porcine adipose tissue-derived stem cells into glucose-responsive insulin-secreting clusters. PLoS One 2017;12:e0172922

38. Ouyang Z, Li W, Meng Q, Zhang Q, Wang X, Elgehama A, Wu X, Shen Y, Sun Y, Wu X, Xu Q. A natural compound jaceosidin ameliorates endoplasmic reticulum stress and insulin resistance via upregulation of SERCA2b. Biomed Pharmacother 2017;89:1286-1296

39. Cui C, Merritt R, Fu L, Pan Z. Targeting calcium signaling in cancer therapy. Acta Pharm Sin B 2017;7:3-17

40. Jian L, Ling-Peng W. GW27-e0977 The research of L type calcium channel in Turn SERCA 2a genetic model for acute atrial fibrillation atrial muscle cell. J Am Coll Cardiol 2016;68(16 Suppl):C35 